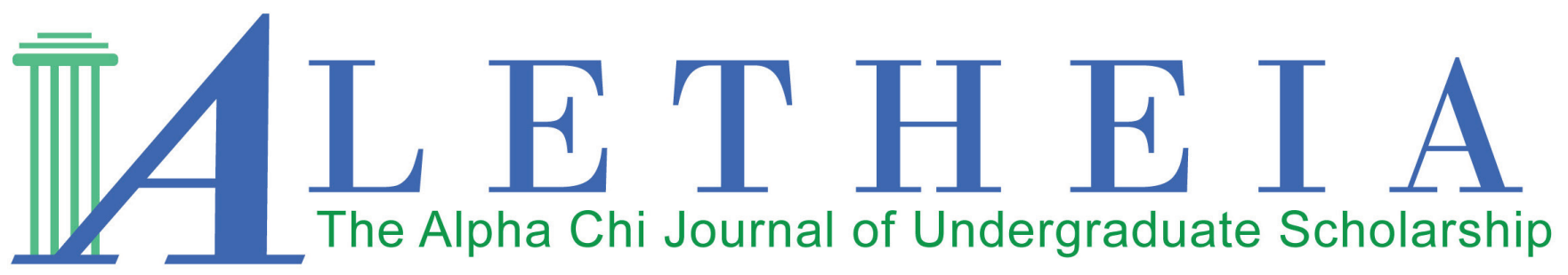

Volume 3 | Issue 2 | 2018

\title{
William Blake and the Industrial Revolution
}

\author{
Dustin Connis
}

\author{
Hawai'i Pacific University \\ Hawai'i Beta Chapter
}

Vol. 3(2), 2018

Title: William Blake and the Industrial Revolution

DOI:

ISSN: $2381-800 \mathrm{X}$

Key Words: William Blake, Industrial Revolution, The Marriage of Heaven and Hell, Prolific, Devourer, Songs of Innocence and of Experience

This work is licensed under a Creative Commons Attribution 4.0 International License.

Author contact information is available from tlindblom@alphachihonor.org or kvosevich@alphachihonor.org

\section{Aletheia-The Alpha Chi Journal of Undergraduate Scholarship}

- This publication is an online, peer-reviewed, interdisciplinary undergraduate journal, whose mission is to promote high quality research and scholarship among undergraduates by showcasing exemplary work.

- Submissions can be in any basic or applied field of study, including the physical and life sciences, the social sciences, the humanities, education, engineering, and the arts.

- Publication in Aletheia will recognize students who excel academically and foster mentor/mentee relationships between faculty and students.

- In keeping with the strong tradition of student involvement in all levels of Alpha Chi, the journal will also provide a forum for students to become actively involved in the writing, peer review, and publication process.

- More information can be found at www.alphachihonor.org/aletheia. Questions to the editors may be directed to tlindblom@alphachihonor.org or kvosevich@alphachihonor.org.

\footnotetext{
Alpha Chi is a national college honor society that admits students from all academic disciplines, with membership limited to the top 10 percent of an institution's juniors, seniors, and graduate students. Invitation to membership comes only through an institutional chapter. A college seeking a chapter must grant baccalaureate degrees and be regionally accredited. Some 300 chapters, located in almost every state, induct approximately 11,000 members annually. Alpha Chi members have been "making scholarship effective for good" since 1922.
} 


\title{
William Blake and the Industrial Revolution
}

\author{
Dustin Connis \\ Hawai'i Pacific University \\ Hawai'i Beta Chapter
}

\begin{abstract}
This paper examines William Blake's concept of the Prolific and the Devourer from The Marriage of Heaven and Hell and discusses how it can be viewed as a criticism of the state and church during the time of the Industrial Revolution. Evidence is also brought in from some of Blake's other works, such as Songs of Innocence and of Experience.
\end{abstract}

Key words: William Blake, Industrial Revolution, The Marriage of Heaven and Hell, Prolific, Devourer, Songs of Innocence and of Experience

Born on November 1757 in London, England (Reinhart), William Blake was a Romantic poet who combined visual art with poetry in his engravings. Blake's work was highly critical of society at large, but his criticism was especially directed at the established Anglican Church. His works placed the wrongs of the Church up front and center and did not apologize for violating what society considered sacred and unquestionable at the time. While Blake's criticisms of religion were well noted, what is less discussed is that his criticism was also directed at the wrongs the working class experienced during the Industrial Revolution. Before the repeal of the Test and Corporation Acts in 1828, members of the House of Commons had to be part of the Anglican Church (Mermagen and M.D.C. 143). This means that the Anglican Church had a large amount of political power at the time, and it was difficult to separate where the Church ended and the state began. Having witnessed the beginning of the Industrial Revolution and the social changes it brought, William Blake used his poetry as a means to protest the Anglican Church's justification of the unfair conditions the working class endured during the Industrial Revolution. Blake accomplished this through the usage of his concept that the needs of the body and of the soul must be kept separate from one another.

Before he became a poet, Blake was a child experiencing great social change that would later shape his writing. Blake lived a relatively peaceful childhood in a middle-class family, and before he began etching copper plates with acid, he developed a reputation as a mystic. Charles Reinhart, a professor of English, writes that Blake's "unique mental powers would prove disquieting. According to [Alexander] Gilchrist, on one ramble he was startled to 'see a tree filled with angels, bright angelic wings bespangling every bough like stars" (par. 3). This mysticism of Blake's led him to view the world in a spiritual manner, and although it disturbed his parents, they encouraged him to develop his artistic talents by having him learn engraving under James Basire (Rein- 
hart par 4). It did not take long for Blake to combine his spirituality with his engraving since the art lessons he learned under Basire contributed to his ability to create his work.

Blake's first published work, There is No Natural Religion, was published in 1788. This was the first time he practiced "illuminating writing," a technique that involved using liquid to create a design on a copper plate and later using acid to burn the liquid into the copper The copper plates were then used to print their designs onto paper, which then had to be hand-colored in order to produce the final product. Blake credited the idea to the spirit of his youngest brother, Robert (Reinhart par. 5-6). Robert's death in 1787 (Roberts 9) was hard on Blake, and it would influence the spiritual themes of his work. "Illuminating writing" would prove to be an effective way to present poetry as it is a blend of both visual art with text.

Although this mode of writing was powerful, it would also prove to be the reason Blake died in obscurity. Blake's plates, although beautiful, were a labor-intensive process to produce. Not only did Blake have to draw the images in reverse so they would copy from the plates to the paper properly, he also had to hand-color every page he printed. As a result of how much effort was required to publish his work, Blake was not able to create many copies of his poems. As it stands, there are only nine known copies of The Marriage of Heaven and Hell ("Editorial note" 4). It is also important to note that during Blake's lifetime, the printing press was being perfected ("The Romantic Period" 21). Due to the handcrafted nature of his work, Blake had little product to distribute and was competing against other writers who were able to publish more copies of their work through the printing press; illuminating writing resulted in Blake not being able to reach many readers in a time when books were able to be copied with relative ease.

Few people read Blake's works while he was still alive. Charles Swinburne, when he wrote a critical essay on Blake in 1868, roughly forty-one years after Blake's death in 1827 , remarked that

In the year 1827, there died, after a long dim life of labour, a man as worthy of remark and regret as any then famous. In his time he had little enough of recognition or regard from the world; and now that here and there one man and another begin to observe that after all this one was perhaps better worth notice and honor than most, the justice comes as usual somewhat late. (Swinburne iii)
If Alexander Gilchrist did not label Blake as a major literary figure in his book, Life of William Blake, published in 1863 (Reinhart par. 146), it is likely that Blake would never have been known by the literary community. This also means that although Blake wrote to protest the Industrial Revolution, he did not have the outreach to alter the opinions of the population; the printing press simply did not support the medium of writing he chose.

The Industrial Revolution itself was not kind to the working class. Although it would eventually lead to an increase of real wages for workers after 1800, wages overall went down in the beginning of the Industrial Revolution (Clark 1311). The wages of the adult middle-class did not increase between 1755 and 1819 (Williamson 688). Workers often did not have a choice as to what type of job they wanted to do. The process of enclosure, although it was necessary for the revolution, destroyed whole villages, which, in turn, forced workers to either move into an industrial town or attempt to live as farm laborers, which was a job that paid starvation wages as much as charity ("The Romantic Period" 7). Socially speaking, many of these workers from villages that were broken up had no choice but to become workers in factories or mines in order to make ends meet, which placed them in the perfect position to be exploited. To further complicate the Industrial Revolution, adult men were not the only workers. According to Sara Horrell and Jane Humphries, both from the University of Cambridge's faculty of economics, "Economic historians appear to agree that the Industrial Revolution involved an increase in child labor" (485). Children worked alongside the adults in the Industrial Revolution, especially if their fathers were laborers; if a child's father worked as a miner, factory worker, an outworker, or in low-wage agriculture during 1787 to 1816 , there was a good chance that that child also worked (497). Blake spent his childhood during a transitional phrase into the Industrial Revolution in which the social impacts were the strongest and the future was uncertain. He saw workers earning low wages and children being exploited for the gain of the elite. It was this image of society being confined by the establishment that Blake had in mind when he wrote his works.

Blake's criticisms toward the Anglican Church, which ties into the Industrial Revolution, are present in one of his short stories in The Marriage of Heaven and Hell. This short story describes the mythology Blake used when studying the circumstances of the world around him. He writes that 
Thus one portion of being, is the Prolific, the other, the Devouring: to the devourer it seems as if the producer was in his chains, but it is not so; he only takes portions of existence and fancies that the whole... These two classes of men are always upon earth, \& they should be enemies; whoever tries to reconcile them seeks to destroy existence. Religion is an endeavor to reconcile the two. (The Marriage of 3)

Blake categorized humans into one of two categories, the Prolific and the Devourer. This ties into Blake's concept of good versus evil. He did not refer to good and evil by their literal meanings, but rather as the need of a certain energy. Blake explains that "Good is the passive that obeys Reason. Evil is the active/ springing from Energy. Good is Heaven. Evil is Hell" (The Marriage of $33)$. In other words, good refers to the desire of the human soul to obey reason, while evil refers to the desires of the human body. The Prolific are those who favor the body's energies, while the devourers favor the soul The needs of the body and soul must be always warring and kept separate from each other to exist rightly. The Prolific create while the Devourers work to make sense of what it is they made. As Blake writes, "The Prolific would cease to be Prolific unless the Devourer as a sea received the excess of his delights" (43). If the Prolific did not create material for the devourers to make sense of, then there would be nothing left to be discovered and if the Devourers were to not make sense of what the Prolific create, then there would be no need to continue the process of creation. If either side is satisfied with the production of the other, there would be nothing to create and later apply reason to.

Blake would likely consider himself as one of the Prolific since he was scornful of the Devourer. That said, he did realize the importance of having a good counterpart to evil, but it is when the soul oversteps its boundaries and attempts to control the needs of the body that Blake takes issue. In her article, "William Blake: A Study of His Doctrine of Art," Marica Brown Bowman observes that "Blake believed that without contraries there could be no progression" (63). The Prolific and Devourer must be kept separate since the joining of these two opposite forces is unnatural and threatens creation. Blake defined religion as an effort to force the energies of the soul and body, or more specifically, to force the reason of the soul to repress the sexual desires of the body. Blake argued that, "Those who restrain desire, do so because theirs is weak enough to be restrained and the restrainer of reason usurps its place \& governs the unwilling" (The Marriage of 34). The weak will try to repress their bodies' desires, and in the process of doing so, they also repress the bodily desires of those around them.

This description of the body versus the soul can be applied to the Industrial Revolution. The working-class was expected by society to work long hours in the factories or mines with little pay to show for it, and the same was expected from children. The needs of England as a society can be seen as the soul, or the Devourer, while the workers themselves can be seen as the Prolific, or the needs of the body. The workers produced the products that England needed in order to thrive, but the long hours and low wages is a case of the Devourer overstepping its authority and trying to impose its needs on the workers by expecting them to work against what is most pleasurable for them. The Industrial Revolution was an attempt to force the workers to repress their desire to enjoy their life and energies and instead focus on difficult and often dangerous work.

The workers tolerated the working conditions because they were told that their working was the desire of God. The Church made little effort to repeal or recognize the social changes brought about by the Industrial Revolution, and in many ways, the Church stood to gain from the exploitation of the working-class. As a state institution, the Church was responsible for "charity," and it used that position as a way to elevate itself in the eyes of the public. When there is more suffering, there are more opportunities for the Church to demonstrate itself as just (an example can be seen in Blake's pair of poems, "Holy Thursday"), which, in turn, can make the people more inclined to follow in the Anglican faith. A large part of the Anglican Church was the tithe it required its members to pay. When there were more Church followers, the Church had more people paying tithes, which helped it fill its coffers. Blake grew up witnessing this exploitation, and he would later live to experience the American and French Revolutions (Reinhart par. 1). These two revolutions questioned the relationship between the people and government; however, since it was hard to tell the difference between the state and Church, these revolutions questioned people's relationships to both the government and church. It was these questions to which Blake applied his mysticism, and professor of English James Swearingen notes that Blake had always questioned these relationships: "Blake's lifelong oppo- 
sition to tyranny took various forms: association with radical causes in his youth, a certain disillusion with politics in his mature years, and a grand vision of human liberty in the late works" (125). Blake saw revolutions as necessary for establishing a balance between the soul and body since the needs of the state were put above the needs of individual people; in other words, Blake saw that the common people did not have to suffer by the hand of the state and Church and set about to show that the justifications given for their suffering was moot.

Blake's resistance to the claims of the Church is best seen in "A Memorable Fancy" from The Marriage of Heaven and Hell. In this story, the narrator encounters an angel who says, "O pitiable foolish young man!... consider the hot burning dungeon thou art preparing for thyself to all eternity, to which thou art going in such career" (45). The angel then forcefully brings the narrator to hell, and it is a terrible place with rivers of blood and a leviathan, but as soon as the angel leaves, hell turns into a pleasant stream with a harper singing. Noticing this change, the narrator returns to the surface and forces the angel into heaven, where there are "a number of monkeys... grinning and snatching at one another, but withheld by the shortness of their chains" (46). These monkeys keep multiplying and cannibalizing one another, especially the weaker ones who cannot defend themselves against the stronger ones (45-7). The only reason hell appeared to be a terrifying place is because the angel, who embodies the Devourer, entered the land of the Prolific. The angel declares that hell is terrible, and it is that claim that makes it so. The narrator explains this transformation to the angel: "All that we saw was owing to your metaphysics" (46). Blake also showcased that the power of perception works the other way around when a Prolific being enters heaven and turns it into a nightmarish realm. The narrator explains to the angel that "We impose on one another, \& it is but lost time to converse with you whose works are only Analytics. Opposition is true friendship" (47). Hell and heaven are both paradises in their own right, so long as they are not intruded upon by those outside of their group. If one side imposes upon the other, then that paradise is lost due to the unnatural combining of the two forces.

What is interesting about "A Memorable Fancy" is that one of the images Blake decided to draw was the leviathan in the river of blood. Although both the leviathan and the monkeys are the products of the Prolific and the Devourer imposing upon one another, Blake emphasized what hell appears to be when the Devourer intrudes upon it. This suggests that the Devourers, and, therefore, the desire to repress, intrudes upon the Prolific and their bodily desires more than the Prolific intrude upon the Devourers. What is also worth noting is that the angel is ignorant of what is happening: "Thy phantasy has imposed upon me \& thou oughtest to be ashamed" (47). Angels are generally shown as the agents of wisdom, but in this short story, this angel is presented as unknowing and ignorant of the power of imposing an ideology that is not natural to a subject. In this case, the angel, who embodies the Church and society, does not know what is best for the natural world to function and instead seeks to condemn all who do not share his view of the world. In his ignorance and arrogance, the angel threatens creation. This forced repression is what caused the public to lose sight of what it means to live a good life.

Unnatural repression allowed unethical acts to be tolerated. In Songs of Innocence and of Experience, Blake created two narrators who describe the same setting in the time of the Industrial Revolution but have different outlooks of the world. The first narrator is innocent and has a positive perspective of the world, while the second narrator comes off as older, more experienced, and able to see through the illusions of the world. In the pairs of poems "The Chimney Sweeper" and "Holy Thursday," Blake's narrators comment on the labor children were forced into. "The Chimney Sweeper" was critical of parents who allowed their children to fall into servitude, while "Holy Thursday" shunned the church officials who used children as a means to make themselves look holy to the publicand to prepare a generation of poor children for labor.

In the innocent version of "The Chimney Sweeper," the narrator describes a boy who is scared of being a chimney sweeper because of the tragedy he suffered (he lost both his parents) and the dangers of being a sweeper. He accepts his fate, however, when he has a dream from heaven that tells him, "So if they all do their duty, they need not fear harm" (Songs of 122). The narrator in Songs of Experience is not comforted so much as shocked, and asks, "Where are thy father \& mother? Say?" (128) and later answers that "They are both gone up to the church to pray" (128). The experienced narrator sees the injustice and recognizes it as such. Both narrators contribute to the story of the chimney sweeper, who is an example of a child being forced into labor by 
society. The image Blake drew of the experience version of the poem shows the chimney boy walking through the snow under thick rain with nothing to protect him from the elements. Furthermore, there are two buildings in this image, but neither of them has a chimney on their roof at the angle they were drawn. The lack of chimneys for the weathered boy to clean suggests that his work is without purpose other than to make him an obedient member of society who respects the authority of the church and public officials. His blank stare off to the side reflects his feelings: "Because I was happy upon the heath... They clothed me in the clothes of death" (128). $\mathrm{He}$ is repressed by having reason imposed upon his happiness, which ends up hurting his being more than helping.

"Holy Thursday" also demonstrates the exploitation of children, but unlike "The Chimney Sweeper," it is a direct criticism of the Church. In the innocent version of the poem, the narrator describes the scene of children singing for the Church as "their innocent faces clean/... Now like a might wind they raise to heaven the voice of song" and the priests who watched them are "aged men wise guardians of the poor" (123). Again, the experienced narrator has an entirely different reaction to the event: "Babes reduced to misery.../ Is that trembling cry a song?/ Can it be a song of joy?" (127). In these two poems, we can see the contrast between the image the Church wanted to impart and what the setting actually looks like once the illusion is dispelled. Charles Reinhart from Vincennes University writes that "The brutal irony is that in this world of truly 'innocent children' there are evil men who repress the children... and force them to show their piety" (par. 32). When the Church succeeded in its repression of the children, they were able to exploit them as a way to make themselves seem as the wise champions of the common people, when the reality was the exact opposite.

This exploitation of children was not just for the Anglican Church to present itself as being morally upright, but it was also to prepare the children to become laborers in the Industrial Revolution. According to David Fairer, a professor of eighteenth-century literature, Blake's "Holy Thursday" is based on how "In thousands of parish churches throughout the country... the body of children from the local charity school was a familiar sight making its way to the weekly service, and once or twice a year... they were publicly on display for the purpose of raising money" (543). In this way, the chil- dren were used as a commodity for the Church to raise funds, but there was another goal in this display of the children - to make them laborers. Fairer pointed to a 1755 meeting, in which the Bishop of Norwich told the assembled members of the charity schools that

There must be drudges of labour... as well as Counsellors to direct, and Rulers to preside... These poor children are born to be daily labourers, for the most part to earn their bread by the sweat of their brows. It is evident then that if such children are, by charity, brought up in a manner that is only proper to qualify them for the rank to which they ought not to aspire, such a child would be injurious to the Community. (Bishop of Norwich qtd. in Fairer 543)

The bishop told the members of the charity school that the children in their care must be taught how to be good laborers and that they should not prepare the children for anything else. The charity schools were directed to narrow the aspirations of the children so that when they became adults, they would desire nothing else but to do manual work in the Industrial Revolution. Going back to Blake's analogy of the Prolific and Devourer needing to be kept separate, the Anglican Church purposefully repressed the children before they could explore who they were; as the angel turned Hell into a terrible place by forcing his expectations upon it, the Church turned the children into laborers of the state by forcing its expectations upon them, therefore turning their lives into suffering.

The priests in "Holy Thursday" and the parents in "The Chimney Sweeper" are the product of the angel's ignorance in "A Memorable Fancy." The Church claimed that repression was the best way to ensure that the people stayed on the virtuous path, but it instead set the stage for unethical actions to take place by encouraging the ideology that hard labor made for a good life. The priests follow in the angel's example by trying to force the needs of the soul (and state) upon the needs of the body (the children), and the parents do not know any better because they are told by an authority of the Church that repression and servitude are the keys to being good. Like the narrator of "A Memorable Fancy" having his paradise turned into a hell, the children were forced during the prime of their childhood to be the tools of others; they were denied a time that should have been their own paradise. The Industrial Revolution was the time when child labor became more common (Horrell and Humphrises 485), and the Anglican Church encour- 
aged it. Blake was protesting how the state forced the workers into unfavorable conditions and how the common people saw it as normal for children to be exposed to similar conditions (as was seen by the parents who let their child be a chimney sweeper) and for the children to be denied any future that allowed for class mobility beyond labor (Fairer 543). The church encouraged the state to repress not only the needs and pleasures of the people, but also the needs and pleasures of the children. The needs of the state's production were forced onto the common population, much like the angel repressed the narrator by forcing the soul upon the body.

Blake's most direct commentary on the Industrial Revolution is perhaps in his work The Visions of the Daughters of Albion. This poem is the story of the virgin Oothoon and her decision to embrace her adult sexuality. However, she is soon assailed and raped by Bromion, and to make matters worse, Theotormon becomes jealous of Bromion and forces him and Oothoon to be bound back to back to each other. This passage in particular spoke of the injustice of being forced into marriage with an undesirable person.

Till she who burns with youth. and knows no fixed lot, is bound

In spells of law to one she loaths; and must she drag the chain

Of life, in weary lust? ...

Of a harsh terror driv'n to madness, bound to hold a rod

Over her shrinking shoulders all the day; \& all the night

To turn the wheel of false desire, and longings that wake her womb...

Till the child dwell with one he hates, and do the deed he loaths,

And the impure scourge force his seed into its unripe birth... (Blake qtd. in Aers 502)

Notice how the terms "In spells of law to one she loaths" and "To turn the wheel of false desire" sound similar to the conditions workers had to go through during the Industrial Revolution. They were bound by law to continue working in order to make a living, whether they liked it or not. Aers, a professor of English, writes that "in the world Blake examines, sexual activity is itself absorbed into the nexus of social controls and containment. The phallus becomes a mere instrument of punitive control reflecting the workmaster's 'rod' and 'scourge'; while 'lovely copulation' is remade in the image of alienated labour, compulsively and joylessly turning the "wheel of false desire"" (6). Blake used physical activity to describe the difficulty of managing sexual repression when bound to a partner one does not feel affection toward. The population was much like Oothoon, forced to be ripped from their homesteads and work in the factories and mines of the industrial towns. This relates back to the concept of the Prolific and Devourer in that the imposing of one of these forces upon the other causes repression. Oothoon is repressed by Bromion and Theotormon, and the result is that she must live out the rest of her life without true joy. Her forced bondage to Bromion is the same as a worker's bondage to the factory; in both cases, their joy is sacrificed in order to fulfill the agenda of another person's desire.

It is through his concept of the ever-lasting war between the desires of the body and the desires of the human soul that William Blake was able to argue against the oppressive conditions the people of Britain faced during the Industrial Revolution. The Anglican Church supported the exploitation of people during the Industrial Revolution and Blake took issue with how the state and Anglian Church worked to encourage the people of the lower social classes to make their living through hard labor, which he saw as the repression of the body's needs (the people and children) by the needs of the soul (the state). By forcing the state and Church's needs over the needs of individuals, the people who worked in the factories of the Industrial Revolution were forced to have the paradise of their lives turned into living misery, and so long as the state and Church did not notice (or neglected to notice) that forcing their needs upon the people was unnatural, the world would be miserable, just like how the angel turned hell into a nightmarish place. While wages did eventually get better (Clark 1311), and between 1840 and 1872 child labor became less common (Horrell and Humphrises 485), these social issues were not yet confronted; Blake wrote to protest the Industrial Revolution before the Victorians would later take up the issue. He was ahead of his time by addressing an issue that few others were disturbed by, and that could very well contribute to why he died an obscure poet before later generations took notice of his work. 


\section{Works Cited}

Aers, D. "William Blake and the Dialectics of Sex." ELH, vol. 44, no. 3, 1977, pp. 500-14, www.jstor.org.hpu.idm.oclc. org/stable/2872570. Accessed 22 Oct. 2016.

Blake, William. The Marriage of Heaven and Hell (Illuminated Manuscript with the Original Illustrations of William Blake). e-artnow, 2013.

---. Songs of Innocence and of Experience. The Norton Anthology of English Literature, edited by Deidre Shauna Lynch and Jack Stillinger, W. W. Norton \& Company, 2012, pp. 118-35.

Bowman, Marcia. "William Blake: A Study of His Doctrine of Art." The Journal of Aesthetics and Art Criticism, vol. 10, no. 1, 1951, pp. 53-66, www.jstor.org.hpu.idm.oclc. org/stable/426788. Accessed 22 Oct. 2016.

Clark, Gregory. "The Condition of the Working Class in England, 1209-2004." Journal of Political Economy, vol. 113, no. 6, 2005, pp. 1307-40, www.jstor.org.hpu.idm. oclc.org/stable/10.1086/498123. Accessed 22 Oct. 2016.

Editorial note. The Marriage of Heaven and Hell (Illuminated Manuscript with the Original Illustrations of William Blake), by William Blake, e-art now, 2013, p. 4.

Fairer, David. "Experience Reading Innocence: Contextualizing Blake's "Holy Thursday." Eighteenth-Century Studies, vol. 35, no. 4, 2002, pp. 535-562, http://www.jstor. org.hpu.idm.oclc.org/stable/pdf/30054004.pdf?refreqid=excelsior\%3A7d48cf5fd55e8730b841e5bdfa88acb5. Accessed 30 May 2018.

Horrell, Sara, and Jane Humphries. "'The Exploitation of Little Children': Child Labor and the Family Economy in the Industrial Revolution." Explorations in Economic History, vol. 32, no. 4, 1995, pp. 485-516, www. sciencedirect.com.hpu.idm.oclc.org/science/article/pii/ S0014498385710212. Accessed 20 Sept. 2016.

Mermagen, Robert, and M.D.C. "The Established Church in England and Ireland: Principles of Church Reform." Journal of British Studies, vol. 3, no. 2, 1964, pp. 143-151, www.jstor.org/stable/175341. Accessed 29 Nov. 2016.

Reinhart, Charles. "William Blake." British Romantic Poets, 1789-1832: First Series, vol. 93, 1990, hpu.idm. oclc.org/login?url=http://go.galegroup.com.hpu.idm. oclc.org/ps/i.do?p=GLS\&sw=w\&u=hono53192\&v=2.1 \&it $=$ r\&id=GALE $\% 7 C H 1200002463 \&$ asid $=$ cf08bc21d031b4880ed4534fc22c1a18. Accessed 22 Oct. 2016.

Roberts, Jonathan. Reader's Guides: William Blake's Poetry (1). Continuum, 2007.

"The Romantic Period." The Norton Anthology of English Literature, edited by Deidre Shauna Lynch and Jack Stillinger, W. W. Norton \& Company, 2012, pp. 2-30.

Swearingen, James. "William Bake's Figural Politics." EHL, vol. 59, no. 1, 1992, pp. 125-144, www.jstor.org.hpu.idm. oclc.org/stable/2873421. Accessed 22 Oct. 2016.
Swinburne, Algernon. William Blake: A Critical Essay. J.C. Hotten, 1868.

Williamson, Jeffrey G. "Why Was British Growth So Slow During the Industrial Revolution?" The Journal of Economic History, vol. 44, no. 3, 1984, pp. 697-712, www. jstor.org/stable/2124148. Accessed 1 Dec. 2016. 